Martin Lang

University of Lincoln

\title{
Spectacular Malaise: Art \& the End of History
}

\section{Abstract}

This article makes two main claims: that Debord's concept of the 'integrated spectacle' is related to end of History narratives; and that the related concept of 'disinformation' is manifested in new forms of media-driven warfare. These claims are substantiated through a comparative analysis between Debord's texts and contemporary politics, primarily as described by Adam Curtis and by the RETORT collective. The resulting understanding of our contemporary politics is a situation where subjects who appear to be free, are in fact only free to choose between competing brands of neo-liberalism that manipulate and baffle in order to obfuscate their true agendas. This situation is termed a 'spectacular malaise'.

The article then critiques post-Marxist claims to a re-birth of History and therefore a potential end to the spectacular malaise. It argues that the Arab Spring and Occupy movement did not signal an end to the end of History, as they were unable to articulate an alternative vision. This situation is compared to the last days of the Soviet Union, when change also seemed unimaginable. It identifies Mark Fisher's call for activists to demonstrate alternative possibilities and reveal contingency in apparently natural orders to counter the spectacular malaise. Three art collectives are considered as potential candidates to take up this challenge: Women on Waves, Voina, and Superflex.

The article concludes that while making actual social and political change is useful for demonstrating alternative possibilities, it is art's symbolic value that reveals contingency and strikes at the heart of the spectacular malaise. 
Key Words:

spectacle,

disinformation,

post-politics,

end of History,

rebirth of History,

Women on Waves,

Voina,

Superflex, 


\section{Introduction}

There is significant evidence that the Situationist International (1957-1972) played an important role in the events of May 1968. We know they worked with students to coauthor pamphlets in the lead-up to the student occupations, which they were also involved in from the start (Dark Star 2001: 6). They were also involved with the Atelier Populaire, who produced many of May 1968's iconic posters from the occupied lithography studios of the Ecole des Beaux Arts (Considine 2015). The sheer number of prints produced indicates that the Situationists could not have been working alone. The Council for the Maintenance of Occupations (CMDO) - a revolutionary committee formed at the Sorbonne University - has been described as 'Situationist inspired' (Seidman, 2004). Situationist Rene Viénet claimed that the CMDO 'was more or less constantly made up of about ten situationists and Enragés (among them Debord, Khayati, Riesel and Vaneigem)' (2014).

Guy Debord's Society of the Spectacle and Raoul Vaneigem's The Revolution of Everyday Life (two of the Situationists' best-known texts) were both published in 1967. Quotations from Vaneigem's book were seen as graffiti slogans. Other graffiti slogans attributed to the Situationist International include: 'Boredom is counterrevolutionary'; 'No replastering, the structure is rotten'; 'Occupy the factories'; 'Under the paving stones, the beach'; 'Art is dead, let's liberate our everyday life' (Knabb 2006: 453-455). In a move that resembled a real-life manifestation of situationist ideas about revolution and everyday life, the CMDO called for the distribution of its slogans by any means, including in cinemas, comics, leaflets, and even 'painting on walls - texts daubed over paintings in the Sorbonne... texts written on posters on the underground' (Fišera 1978: 125). These slogans included the suspiciously Situationist-sounding 'Down with spectacle-commodity society'; 'Abolish alienation'; and 'Humanity won't be happy till the last bureaucrat is hung with the guts of the last capitalist' (Knabb 2006: 455).

The concept of 'spectacle' famously developed by Debord (1931-1994) throughout his seminal book, Society of the Spectacle is widely acknowledged to have influenced 
the events of May '68 (Gallix 2009; Knabb 2011; Kurczynski 2010; Lasn 2000: xvi; McKee 2016; Wollen 1989: 67, 71). Both Vaneigem and Debord wrote about the alienating effects of spectacle, which they saw as a direct result of consumer capitalism: May 1968 was their attempt to destroy it. During the unrest, Situationist graffiti slogans about spectacle could be seen around Paris. Examples include: 'Comrades, stop applauding, the spectacle is everywhere'; 'Don't get caught up in the spectacle of opposition'; 'Oppose the spectacle'; and 'Down with spectacle-commodity society', (Knabb 2006: 458). CMDO slogans such as 'Down with a society based on commodity production and the spectacle' (Fišera 1978:125), hint that May '68 was (at least partially) a revolution against spectacle.

This article will analyse how spectacle has evolved since 1968. It likens Debord's updated version, the 'integrated spectacle' conceptualized in his Comments on the Society of the Spectacle (1998), to a post-political malaise that arose a few years later, after the fall of the Berlin Wall and the collapse of the Soviet Union. This condition is termed 'spectacular malaise'. The spectacular malaise itself has mutated and evolved through the increased application of Debord's concept of 'disinformation' (1988), evidenced in the modern phenomena of 'non-linear' and 'spectacular' warfare and in the modern media - which Adam Curtis refers to as 'oh-dearism'.

The article asks if History really ended, as Francis Fukuyama famously declared (1992), in the era of what Debord called 'spectacular consensus' following the demise of the USSR. Post-Marxist attempts to assert a rebirth of History (Badiou 2012; Harvey 2012; Žižek 2012) will be critiqued to argue that the Arab Spring and the Occupy movement did not signal an end to the end of History, as they were unable to articulate an alternative vision. However, an analysis of the last days of the Soviet Union will reveal that change is possible, even when it is most unexpected. Imagination is necessary for the rebirth of History: it is necessary to be able to conceive political alternatives. 
The article will question how artists can play a role in developing such an imagination. It will do this by applying two criteria that Mark Fisher identifies in Capitalist Realism (2009) namely: demonstrating alternative ways of living and revealing the contingencies and inconsistencies of the spectacular malaise. Three art collectives will be considered as potential candidates to take up this challenge: Women on Waves, Voina, and Superflex.

\section{Integrated Spectacle and the Post-Political Malaise}

The first argument to be advanced in this article is that spectacle is linked to a "postpolitical malaise'. In order to make this case, it is first necessary to analyse what Debord meant by spectacle and to discern its three variants. In Society of the Spectacle, Debord warned that 'Everything that was directly lived has receded into a representation' (2004: 7). He developed the definition and concept of spectacle throughout the book, but perhaps it can be concisely summed up as 'a social relation between people that is mediated by images' (2004: 7).

Debord differentiates two forms of spectacle: concentrated and diffuse (2004: 31). Both forms project the appearance of unity and happy harmony to conceal social problems. Debord associates the concentrated spectacle with 'bureaucratic capitalism' found in totalitarian states such as Nazi Germany and the USSR. Dictatorships cannot allow the exploited masses any significant choice, as they alone make the choices (2004: 31). The concentrated spectacle is likened to a police state, whose image is usually concentrated in a single individual (2004: 31-32). The diffuse spectacle, on the other hand, is associated with the community abundance accompanying modern capitalism (Debord 2004: 32). Rather than being concentrated in the image of an individual, it is manifested in the illusion of choice. However, citizens are only really free to choose between different brands of competing commodities. Both concentrated and diffuse spectacles are systems with replaceable parts. We are all familiar with commodities, such as washing powders, that today claim to be perfect only to launch 
new improved versions tomorrow. In the concentrated equivalent the 'faultless' leader, Stalin for example, is later denounced by a new 'faultless' leader (2004: 34-35).

After the counterculture's apparent failure to destroy it, Debord claimed that the spectacle morphed into something worse: a third strand that he called the integrated spectacle (1988). This new type of spectacle evolved as a combination of the previous two, while acknowledging the general victory of the Western capitalist type. Debord identified five key features of the integrated spectacle: constant technological renewal, the integration of the State and economy, generalized secrecy, unanswerable lies and an eternal present. To judge to what degree the integrated spectacle applies to our current situation, each feature will be addresses in turn.

Technological renewal was essential to industrial capitalism. It was no less essential to post-industrialism at the time Debord was writing. Since then, we have seen the rise of the PC, the internet, the smartphone, GPS, voice recognition, driverless cars, and the beginnings of biotechnology. Technology is now in our cars and in our pockets and many of us cannot live without the internet. Integration of the state and the economy appears to have been a less successful prediction, as globalisation has led to the rise in the multi-national. However, states and multi-nationals coexist amicably, as evidenced when Ireland welcomed in Apple and Amazon, knowing that they would pay no tax. Generalized secrecy is the product of the rise in identity theft, phone hacking and fear of losing our data. We all have dozens of passwords to remember now. Unanswerable lies can be seen in post-truth and fake news. As Debord said:

The simple fact of being unanswerable has given what is false an entirely new quality. At a stroke it is truth which has almost everywhere ceased to exist or, at best, has been reduced to the status of pure hypothesis. (1998: 12-13)

Furthermore, if power is unknow, it need not answer to anybody. 'Spectacular government' he tells us 'now possesses all the means necessary to falsify the whole 
of production and perception' (Debord 1998: 10). Debord's 'eternal present' can be seen in $24 \mathrm{hr}$ news with its constantly updating 'breaking' headlines that can be just as instantly forgotten. With the destruction of history comes a 'realm of unverifiable stories, uncheckable statistics, unlikely explanations and untenable reasoning' (Debord 1998: 16). This only prefigured online fads and the cult of disposable 'celebrities'. Pop stars are now made on talent shows and instantly get number one hit singles, before fading into obscurity to allow next season's 'talent' to emerge. 'Meanwhile news of what is genuinely important, of what is actually changing' Debord warns, 'comes rarely' (1998: 13).

Debord's integrated spectacle echoes 'end of History' and 'post-political' narratives. Francis Fukuyama famously saw the collapse of the Soviet empire as signalling liberal capitalist democracy's victory over communism; it was the pinnacle in the political evolution of humankind and therefore, he concluded, we had witnessed the end of History, by which he meant the end of the evolution of systems of government (Fukuyama 1992). Eerily, Debord used the term 'the end of history' in Comments on the Society of the Spectacle (1998: 14), four years before Fukuyama applied Hegel's term to the post-political consensus that followed the demise of the USSR. Debord was referring to the suppression of history, but his integrated spectacle has many facets that recall the Fukuyamian version.

The end of History is synonymous with the term 'post-politics'. ${ }^{1}$ A 'post' political era comes after the apparent victory of one system of government over all others and the end of any possibility for future evolution. The demise of the Warsaw Pact and the integration of Eastern European countries into the European Union seemed to confirm Fukuyama's thesis, but it went deeper than that. In Britain, New Labour moved to the centre, keeping the Conservative Party out of power for a generation. Let us be clear, moving to the 'centre' meant adopting neo-liberal policies. New Labour infamously embraced private finance initiatives (PFIs) from the outset. The NHS (Private Finance) Act 1997 set out their stall and was followed by opening up a massive rebuilding 
programme of state schools to PFI contractors. They also introduced university tuition fees. As there was cross-party support for these initiatives, and for deregulating the financial sector, it could be argued that rather than bringing democracy to Russia, the end of History replaced democracy in the West with the spectacle of choice; voters became free to choose only between competing brands of neo-liberalism. Post-political consensus hinders progress on a systemic level, because it believes that the final system has arrived: there is no alternative and there can be no more progress. It is for this reason that it is also a malaise of imagination.

Debord's integrated spectacle became fully fledged during this post-political malaise. Indeed, the American curator Nato Thompson urges us not to think of the past twenty years as a 'post-Cold War' era but 'as the moment in which the spectacle became the increasing reality for not only culture makers, but all people' (2012: 30). This condition is what I term 'spectacular malaise'.

Writing in 1988, when the collapse of the Soviet Union seemed unimaginable, Debord showed exceptional foresight, writing as if the USSR were already dead and as if the age of what he called 'spectacular consensus' had already arrived.

When there were still conflicting ideologies, which claimed to be for or against some recognised aspect of reality, there were fanatics, and liars, but there were no 'disinformers.' When respect for the spectacular consensus, or at least a desire for spectacular kudos prohibits any honest declaration of what someone is against, or equally what he wholeheartedly approves; and when at the same time he needs to disguise a part of what he is supposed to acknowledge because for one reason or another it is considered dangerous, then he employs disinformation.

(Debord, 1998: 49) 


\section{Disinformation: Spectacular and Non-Linear Warfare}

Debord's concept of disinformation, introduced in the quotation above, predicts the rise of post-truth politics. He asserts that disinformation is that which can oppose a truth, but he contrasts it with straightforward lies or negation of facts, by emphasising the need for a degree of truth manipulated by an artful enemy (1998: 45). Debord goes on to tell us that in France there was once a campaign to install 'free-from disinformation' labels on media sources (1998: 47). However, he notes that authorities would not want to refute disinformation, as this would only draw suspicion about the source. He concludes that 'Where disinformation is named it does not exist. Where it exists, it is not named' (1998: 49).

The second argument advanced in this article is that disinformation is manifested in two new kinds of media-driven warfare: one from Russia and the other from the West. Both recall spectacle in that they are mediated by images and both are surprisingly designed using aesthetic strategies imported from avant-garde art and theatre. Since Debord claimed that the concept of disinformation originated in Russia (1988: 44), we will start with an analysis of the Russian version.

\section{Nonlinear warfare}

Non-linear warfare is a term coined in a short story written by Natan Dubovitsky, who is widely reported to be the penname of Vladislav Surkov, one of Vladimir Putin's closest political advisors (Pomerantsev 2014a; Walker 2016). The short story, entitled Without Sky (2014) is set after the Fifth World War - the first 'non-linear' war. The story describes how warfare evolved from having two opposing countries, sets of allies, or coalitions, to multiple coalitions, not taking two sides, but all fighting against each other and in their own interests. Furthermore, it became rare for whole countries to enter conflicts. Instead, different regions, generations and genders would fight on different sides - and would frequently switch sides. The novella was published just a few days before the annexation of Crimea, where Surkov appeared to put the concept of non- 
linear warfare into practice. BBC documentary filmmaker Adam Curtis alleges that this signalled a new state of war in which you never know what your enemies are up to, or even who they are. The underlying aim, he tells us, is 'not to win the war, but to use the conflict to create a constant state of destabilized perception in order to manage and control' (2016). Joshua Stowell, editor of Global Security Review, concurs with this concise definition:

\begin{abstract}
A nonlinear war is fought when a state employs conventional and irregular military forces in conjunction with psychological, economic, political, and cyber assaults. Confusion and disorder ensue when weaponized information exacerbates the perception of insecurity in the populace as political, social, and cultural identities are pitted against one another.
\end{abstract}

The media is an essential component of non-linear warfare. In the annexation of the Crimea, Russia simply denied all involvement, labelling pro-Russian combatants 'Russo-Ukrainians' or 'volunteers'. By the time people figured out what was really going on, it was over. The confusion Surkov created recalls Orwell's Nineteen Eighty-Four (1949), where Big Brother is able to convince people that Oceania has always been at war with Eurasia and deny the fact that it was ever at war with Eastasia, but non-linear warfare is real.

Disinformation is not only applied in the theatre of war, it is integrated into to all walks of life. Surkov fed the Russian people conflicting information: he used Kremlin money to fund both anti-fascist groups and neo-Nazis; he funded a variety of political parties, including those opposed to Putin; and he funded human rights NGOs as well as nationalist groups who accused the NGOs of being Western puppets (Curtis 2016; Pomerantsev 2014b). Crucially, Surkov then let it be known that this was what he was doing. The aim was to keep any opposition confused, to draw attention away from what 
was really happening, to undermine their very perception of the world, so that they were never quite sure what was really happening (Curtis 2016) and to own all political discourse (Pomerantsev 2014b).

It has been argued that Surkov operates like an artist, by embracing art's paradoxical qualities. An article in The Atlantic describes how Surkov 'sponsored lavish arts festivals for the most provocative modern artists in Moscow, then supported Orthodox fundamentalists, dressed all in black and carrying crosses, who in turn attacked the modern-art exhibitions' (Pomerantsev 2014b). It reports that his first wife was an artist and that Surkov himself claimed that part of his portfolio at the Kremlin included 'Modern art' and the author claims that Surkov's 'genius' was that he was able to marry modern art with authoritarianism (Pomerantsev 2014b). In Hypernormalisation, Curtis points to Surkov's training in theatre and claims that it is from this background that he applied avant-garde ideas to turn 'Russian politics into a bewildering, constantly changing piece of theatre' (2016).

Perhaps Curtis overstates the influence of Surkov's theatre training and artist wife because Curtis himself is already influenced by Debord's concepts of spectacle and disinformation. Curtis does not refer to disinformation, spectacle, or any of Debord's concepts directly in his work or in interviews. Indeed, art critic Nathan Budzinski claims that Curtis 'thinks Debord is too intimidating and obscurantist' (Curtis 2011). Nonetheless, there is evidence that Curtis is both aware of and influenced by Debord's concepts. There are too many similarities for this to be coincidental. For example, there are formal similarities between Curtis' documentaries and Debord's film version of Society of the Spectacle (1973). Both Curtis and Debord narrate over a montage of carefully selected found footage. Curtis' language and critical position are also closely allied to Debord's: both take a gloomy, almost conspiratorial view of their respective contemporary politics. The tone, politics and the formal similarities suggest not only that Curtis is aware of Debord's concepts, but that there are links between them and 
non-linear warfare and, as well shall see, other contemporary phenomena that Curtis describes.

\section{Spectacular warfare}

In the West a parallel development to non-linear warfare emerged in the wake of the September 11 terror attacks. The RETORT collective (lain Boal, T.J. Clark, Joseph Matthews, Michael Watts et al) apply Debord's concepts to what they call 'spectacular warfare' (2004: 5). Like its non-linear sister, spectacular warfare prioritizes obscuring real objectives over actual military victories. The War on Terror, as with the War on Drugs before it, targeted an unobtainable enemy that could never be defeated. The objective was never to gain a military-style victory. Instead, the War on Terror might be seen as cover for what Hal Foster has referred to as military neo-liberalism abroad and political neo-liberalism at home (Foster in RETORT 2006: 8).

For RETORT, in a single moment, 9/11 caused an immortal image of US defeat. Even if it was not a military defeat, it was a spectacular defeat at the level of the image. America was compelled to assert its authority by regaining image superiority. The US military response to $9 / 11$, RETORT theorizes, was really a search for an image to counter this spectacular image-death. However, images of toppled statues, Saddam's capture, or George W. Bush, in a flight jacket aboard an aircraft carrier announcing 'mission accomplished' were not sufficient to undo the damage (at the level of the image) caused by $9 / 11$. Likewise, according to RETORT, it is not possible to '.. destroy the society of the spectacle by producing the spectacle of its destruction' (2004: 20).

In this sense, the Iraq War was 'spectacular', but disinformation was also certainly employed. We now know that Iraq had nothing to do with the 9/11 attacks nor, as we have subsequently learned, did it possess weapons of mass destruction capable of reaching our shores within forty-five minutes. Fake news was blended with conventional warfare to form a spectacular war that attempted to hide its real objectives from the public. However, the largest ever anti-war protests (Walgrave \& 
Rucht 2010) that prefigured the war suggest that many people easily saw through the charade: that the true reason for invading Iraq and Afghanistan was to open up markets to contractors such as Halliburton. ${ }^{2}$ Nonetheless, with a lack of political options the protests became mere spectacles: the war proceeded regardless and Tony Blair's government was re-elected in 2005 .

\section{Oh-dearism}

An argument can be made that media disinformation bewildered, overwhelmed and left people feeling so helpless that they accepted there was no alternative and that resistance was futile. American and British news is so hopeless, depressing, and above all, confusing that it leaves us feeling totally helpless. As Curtis notes, we know the situation is bad, but the only response we are capable of is to say, 'oh dear...' More recent examples of 'oh-dearism' illustrate the kind of cognitive dissonance that pacifies and demands acceptance of the spectacular malaise. We saw a catastrophic collapse in the banking sector, caused in part by major corruption and incompetence, but no one at any significant level was prosecuted: the system (spectacle) had to remain unchallenged. We have also seen the large-scale surveillance of emails and phone calls by government agencies such as the NSA and GCHQ. British newspapers like The News of the World were proven to be hacking the voicemails of celebrities and murdered school girls, but their editor Rebekah Brooks' plea of incompetence was accepted, so she was cleared of all charges (Boffey 2015; Hacked Off 2015). The newspaper was replaced by The Sun on Sunday and its publisher, News International, simply rebranded as News UK. Brooks was re-appointed as the chief executive and business as usual was resumed: oh dear. British forces have withdrawn from Afghanistan, but we are unclear whether we won or lost the war. In Syria, we were told that Bashar al-Assad was the enemy, then a useful ally for defeating ISIS, and then the enemy again. The same pattern is recognisable with Colonel Gaddafi in Libya. The economy is growing, but wages are falling. The deficit is falling, but the national debt is rising. The government is attempting to rescue us by pumping money into the 
economy through quantitative easing, but at the same time it is taking money out of the economy through its austerity programme. To be sure, it is not just Putin and Surkov spreading disinformation. We have our own kind that serves to obfuscate the real mechanisms of power.

\section{The end of the end of History?}

When Debord wrote The Society of the Spectacle, there were at least two competing ideologies and therefore the direction of historical progress was still up for debate. As Debord was formulating his concept of spectacle, ideological conflict was frequently manifested in military conflict - and wars were very close to home. For example, he wrote in the wake of the Algerian War of Independence (1954-1962), where Frenchmen were conscripted. The Situationists wrote about this war and the political situation that followed, on several occasions. Debord was also writing at the height of the Vietnam War (1955-1975), where Americans were famously drafted into a catastrophic war resulting from France's defeat in the First Indochina War (1946-1954). France had recently been defeated in two colonial wars and still had compulsory military service. Furthermore, the 1960s were marked by the Cold War. The Cuban Missile Crisis (1962) demonstrated that war could be on the doorstep for Westerners - at any moment. If you weren't drafted, you might be annihilated in a nuclear holocaust.

If History ended in 1991, with the demise of the Soviet Union, we might expect the post-political era that followed to be one of relative peace. Indeed, a case can be made that from 1991-2001 most Westerners lived untouched by conflict. The Cold War had ended, and nuclear assault became much less likely. Conscription similarly became virtually unimaginable. ${ }^{3}$ In the West, there were fewer terrorist attacks after 1991 than in the 1970s and 1980s (Sanger-Katz 2018). Between the Gulf War ending in 1991 and the War on Terror starting in 2001, the West was involved in virtually no wars, other than in peace-keeping roles in foreign civil wars (such as Bosnia and Somalia). 
9/11 and the terrorist attacks that followed brought physical as well as ideological conflict close to home for the first time in twenty years. ${ }^{4}$

Was this spectacular consensus really the end of History? Some think not. There are those who feel that rage against the neo-liberal logic had been bubbling away inside all the time (Holloway 2012; Sloterdijk 2010; Žižek 2012). These thinkers suggest that the 'accumulations of rage' erupted in events such as the August riots (London 2011). While disparate, the resistance from across the spectrum of rage and violent activity can be read as symptomatic of a global struggle; a struggle which incorporates, for David Harvey, the protestors of Tahrir Square, the students of Chile, the workers striking in Greece and 'the militant opposition emerging all around the world, from London to Durban, Buenos Aires, Shenzhen, and Mumbai' (2012: 164). He concludes: 'the brutal dominions of big capital and sheer money power are everywhere on the defensive.'

Alain Badiou argues that, because of the accumulation of rage, we now 'find ourselves in a time of riots wherein a rebirth of History, as opposed to the pure and simple repetition of the worst, is signalled and takes shape' (2012: 5). He understands Harvey's types of global struggle as actions within a cultural history of revolt that while: 'blind, naïve, scattered and lacking a powerful concept or durable organisation, [...] naturally resemble [...] the first working-class insurrections of the nineteenth century' (2012: 5) Badiou distinguishes three kinds of 'riot': immediate, latent and historical. The August uprisings were an example of an immediate riot: one that breaks out with extraordinary intensity, but ultimately is unable to move beyond its specific time and place and rapidly peters out. Latent riots are the next step. These involve large numbers of people from different backgrounds (students, workers, the unemployed and retired) involved in disruptive mass actions such as strikes, demonstrations and blockades. The historical riot is Badiou's main focus and his key example is the Egyptian Revolution of 2011. In contrast to the immediate riots in the UK, according to Badiou, the gatherings in Cairo's Tahrir Square did not peter out even when faced with 
brutal repression. Instead they grew, drawing in wider layers of people and casting aside previously rigid social distinctions between men and women, religious and secular, Muslim and Christian.

Badiou was premature to declare a rebirth of History. The Internet was used to organize thousands of people into a leaderless revolution capable of toppling Mubarak, a dictator who had been backed by the US for thirty years. Social media might have helped bring people to Tahrir Square, but Curtis correctly observes that 'the internet gave no clue as to what kind of new society they could create in Egypt' (2016). The organisation that did have an idea, The Muslim Brotherhood, was democratically elected to fill the void. By 2013, the liberals who orchestrated Mubarak's downfall welcomed in a military coup to save themselves from Islamism: a deathblow to Badiou's rebirth of History.

The lack of vision for the future regime was structurally inevitable. Protestors insisted on non-hierarchical structures, but with no leaders, communication became problematic. Curtis has likened the development of hand signals, the human microphone and people's assemblies in Tahrir Square and in the Occupy movement to developing 'management systems'. Seen in this way, the spectacular malaise is so entrenched as an ideology that the protestors were unaware that they were adopting its tactics and products. The focus on 'horizontality' functioned in a similar way to disinformation: it masked what was really happening - the avoidance of striking at the system.

Neither the Arab Spring, nor the Occupy movement that followed were able to stimulate a new political imagination, but what about the banking crisis of 2008 ? No one at any significant level was prosecuted and in Britain alone, The Guardian reported, banks were bailed out to the tune of $£ 1.162$ trillion (Anon 2011). There is a convincing argument that austerity measures and banking bailouts demonstrate that change was unimaginable. The system, it seems, had to remain at all costs. However, for Mark Fisher, neo-liberalism after the 2008 is finished as an ideological project with 
confidence in its own momentum. With no apparent credible alternative, it will continue to rule the political-economic unconscious for the time being. To save itself, it might even revert to social democracy or authoritarianism (Fisher 2009: 78).

Fukuyama's End of History asserts that it is impossible to progress beyond liberal capitalist democracy, not that it is impossible to regress into dictatorships, monarchies or other systems of government. Therefore, even if Fisher is correct, it is important to recognize that, a regression into older forms of government is not indicative of a rebirth of History: the spectacular malaise can still bounce back. Badiou fails to see that a return to communism is either a regression, or an end of History narrative of its own: Marx was a proponent of the end of History, except that instead of liberal democracy he saw the communist society as the terminus. Perhaps Fukuyama was right all along - no matter how flawed our current political system, maybe there really is no alternative, as Margaret Thatcher famously declared.

History shows us that we are not, in fact, without hope. Our contemporary situation is surprisingly reminiscent of late Soviet communism that preceded unimaginable change. Curtis explains that by the 1980s everyone in the USSR knew that the economy was falling apart, but they couldn't imagine an alternative. The end to the planned economy was unthinkable, so politicians refused to admit that anything was wrong. Everyone knew this was untrue, but they carried on pretending everything was fine. This charade is described by Curtis, in Baudrillardian fashion, as 'hypernormal' (2016). Fisher draws parallels between Stalinist targets and those employed under neo-liberalism. In his book Capitalist Realism (the term he uses to describe our predicament, which has many parallels with spectacular malaise) he gives several British examples. In education, Ofsted inspections and league tables encourage teaching to the exam, preparing for the inspection and require reaching targets. In the NHS, a target-driven culture sees the prioritising of easier operations to improve success rates, while trollies with patients on them have their wheels removed so they can be re-classified as 'beds' and the corridors in which they sit are renamed as 
'wards'. By contrast to a planned economy, one might expect neo-liberalism to have abolished bureaucracy, but nothing could be further from the truth. Fisher gives the example of how it has failed to do this is the Kafka-esque call centre. Both the Soviet (concentrated) spectacle and our (integrated) spectacular malaise rely on appearances rather than reality.

David Graeber and Gavin Grindon propose returning to Situationist theory to help formulate new political imaginations. Graeber, a well-known proponent of anarchism who played a key role in the formation of the Occupy movement, looks back to 1968 where he identifies a split in French theory:

$[T]$ he pre-1968 revolutionary strain, kept alive in zines, anarchist infoshops, and the Internet, and the post-1968 strain, largely despairing of the possibility of a mass-based, organized revolution, kept alive in graduate seminars, academic conferences, and scholarly journals.

(2009: 259)

According to Graeber, the former strain does recognize the alienating effects of spectacle, but allows for the possibility to rebel against it, while the latter sees spectacle as so all-encompassing that it is impossible to even critique it. Therefore, for Graeber, post- '68 French theory that is popularly read in academia is complicit in end of History narratives. He argues that Situationist texts have a popular readership within activist circles where they are reinterpreted through more libertarian lenses. The reason for their exclusion from academic reading lists, Graeber tells us, is that they can only be read as actual calls to action and a revolutionary rejection of the political system (2009: 260).

Grindon has called for us to consider aspects of contemporary activism 'as reworking the grand claims of the Situationist International' (2009: 51). He identifies a new wave of critical thinkers more 'orientated towards second-wave anarchism, autonomism and various ecological frameworks than towards the Marxian critical 
idiom', (2008: xiii) seeing Hardt and Negri's 'breakthrough' text Empire (2000) as the main enabler for this shift. For Grindon, a noticeable trend in this new wave of writers is an involvement with activism 'on the ground' and therefore a leaning towards a practical application of radical theory - just as the Situationists advocated in 1968. The same could be said of a new generation of politically engaged artists who base their work on grassroots activism and real campaigns in which the artists themselves are often embedded. ${ }^{5}$

\section{How can artists counter the spectacular malaise?}

Artists in some ways resemble a new social class called the 'precariat', which is characterized by new forms of precarious labour as seen in the rise of zero hours contracts and self-employed status while working for a fixed employer (such as Uber or Deliveroo). The very fact that this class has little to no job security means that it is potentially dangerous (Standing 2016). The connection between the precariat and artists has been made by several collectives working at the boundary of art and activism: from the Carrotworkers' Collective, Precarious Workers' Brigade - who work to address 'Institutionalized precarity and the corporatisation of the arts' - (Precarious Workers Brigade n.d.), and the Artists' Union England (UK); to W.A.G.E - Working Artists and the Greater Economy (US), and the German network of 'Free Class' movement. Yates McKee has specifically noted the conjuncture of the precariat and artists in the Occupy movement, highlighting how artists were an integral part of Occupy from the outset. (2016) Graeber goes further to suggest that revolution is in artists' veins:

I [have] asked why it was that even when there is next to no other constituency for revolutionary politics, one still finds revolutionary artists, writers, and musicians. My conclusion: that there must be some kind of link between the experience of non-alienated labor, of imagining things 
and then bringing them into being, and the ability to imagine social alternatives.

(2009: 261)

Art can play many roles, but this article is concerned with artists working in the Situationist avant-garde vein of merging art and life - or more specifically, art activism. Fisher argues that there is a need to demonstrate that History has not ended by destroying the appearance of a 'natural order'. For Fisher, emancipatory politics 'must reveal what is presented as necessary and inevitable to be a mere contingency, just as it must make what was previously deemed to be impossible seem attainable' (2009: 17). I will address some contemporary art activist collectives who could be said to do just this: demonstrate alternative ways of living and reveal contingency in the exiting order.

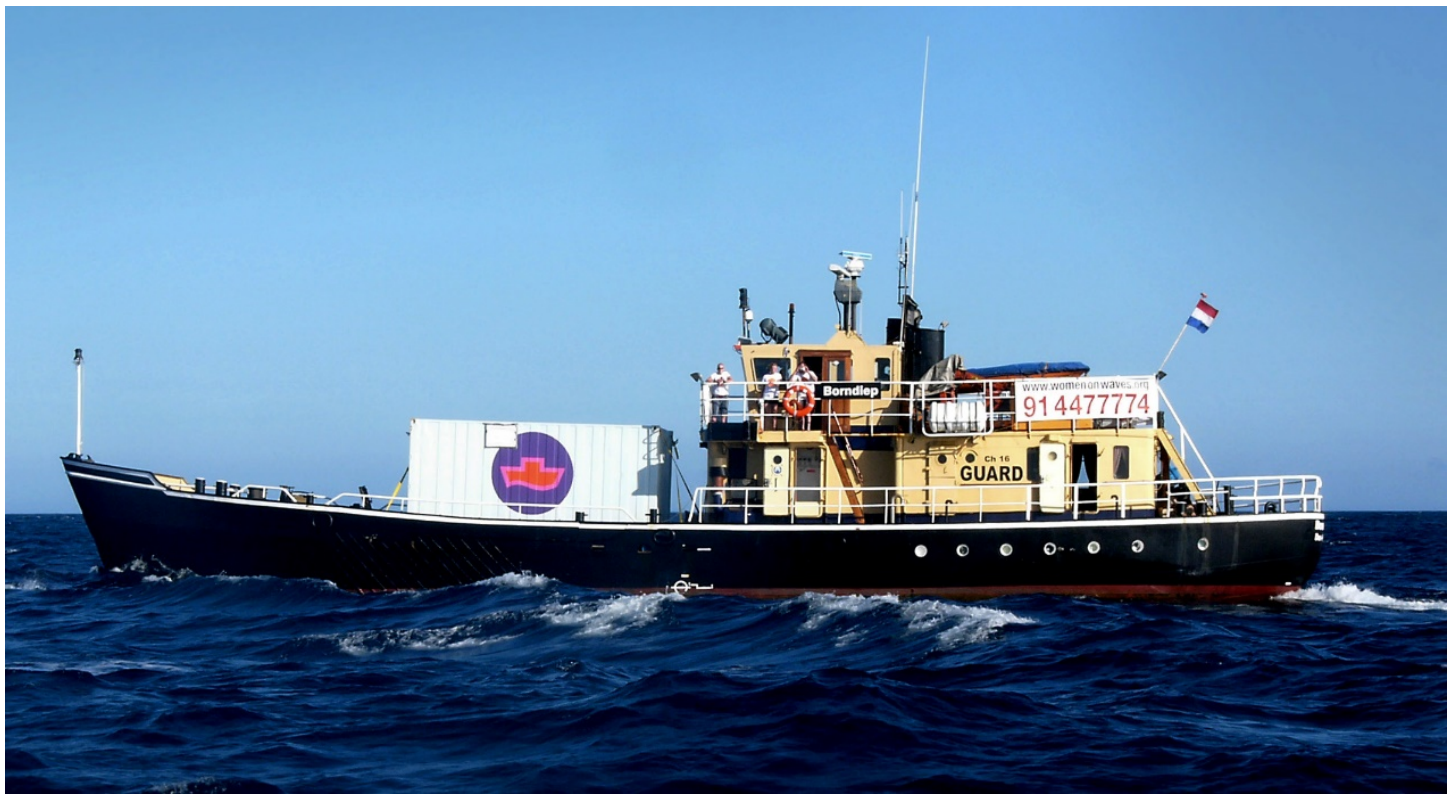

Figure 1: Women on Waves, A-portable aboard the Borndiep, 2004. (c) Women on Waves Foundation. Photo: Women on Waves.

Dutch feminist art activist collective Women on Waves (founded 1999) are not only able to demonstrate and reveal contingency- they actually provide an alternative. They converted a shipping container into a mobile abortion clinic, designed by the renowned art activist Atelier Van Lieshout, who also named it A-Portable. The container is 
installed on ships that Women on Waves charter and sail to countries where abortion is illegal. They moor the ship and offer medical advice, sex education and contraception. They also run workshops 'not only for lawyers and doctors, but also for artists and writers' (Lambert-Beatty 2008: 313). They then sail twelve miles off-shore, into international waters, where they are able to offer sonographs and abortions without breaking the law, since the vessel is registered in the Netherlands it is subject to Dutch law. Harvard art historian Carrie Lambert-Beatty points out the similarity between 'Under the paving stones, the beach' and 'twelve miles from the beach, the Netherlands': both show imagination and a determination to alter the status quo (2008: 316)

However, we should not be too quick to deem Women on Waves a success in Situationist terms; they provide women with access to abortions, but their effect on abortion law is at best negligible. The first country they targeted (Ireland 2001) has since legalized abortion, but the second (Poland 2003) continues to criminalize abortion except when the pregnancy results from rape, incest, or for medical reasons (such as threat to life). In 2015 a measure to implement a complete ban was only narrowly defeated in parliament. In 2018 an amendment was proposed to ban abortion in all cases except where there is a threat to the woman's life. The measure was reversed when tens of thousands of protestors took to the streets in the so-called 'Black Friday Protest' (BBC 2018; Bulman 2018). There are more recent examples of 'tightening up' on anti-abortion laws. On his first day in office President Trump 'signed an executive order to ban federal money going to international groups which perform or provide information on abortions', (BBC 2017) and by 2019 he banned tax-payer funded clinics from making abortion referrals (Associated Press 2019). Abortion is now effectively illegal in nine states - even in cases of rape or incest if new laws come into effect - and several other states have taken measures to restrict abortions (Amnesty International 2019). Women on Waves demonstrate another way of living (one where women are in control of their bodies) and they reveal contingency (the ship is only 
twelve miles off shore), but they do not strike at the system - the spectacle, it seems, remains untouched.

The Russian Voina group could be said to demonstrate political alternatives through daring acts that risk arrest under an authoritarian regime. I will give three examples of such actions. For Dick Captured by FSB (2010) the group's members drew a sixtyfive-meter-high cock and balls on the famous St. Petersburg Liteinyi Bridge. The bridge opens so that the giant phallus is erected opposite the FSB (former KGB) headquarters. A video of them making the action, which shows their subsequence roughing up and arrest, holds a mirror up to Russia's authoritarian spectacle. This action demonstrates a certain lack of fear and lack of respect. In so doing, Voina demonstrate what it might feel like to live in a less authoritarian country.

Cock in Ass (2009) similarly demonstrates how citizens can disrupt and stand up to authoritarian regimes. In this case the group disrupted a court proceeding by playing loud punk music in a move that preceded and prefixed Pussy Riot's activist performance 'Punk Prayer - Mother of God, Chase Putin Away!' (2012) at Moscow's Cathedral of Christ the Saviour. The arrested members of Pussy Riot were all previously members of the Voina group. This demonstrates that Voina have encouraged the formation of new activist groups.

The Voina group's Palace Revolution (St Petersburg 2010) involved turning seven police cars onto their roofs (some of them with police officers inside). The group used the bureaucratic excuse that they were attempting to retrieve a ball: members were arrested. Collectively such acts of disobedience actively demonstrate what it might be like to live in a less authoritarian regime.

Do art activist groups such as Voina and Women on Waves affect real change, or as Curtis warned, merely the spectacle of change?

Even those who thought they were attacking the system - the radicals, the artists, the musicians, and our whole counterculture - actually 
became part of the trickery, because they, too, had retreated into the make-believe world [spectacle], which is why their opposition has no effect and nothing ever changes.

(Curtis 2016)

It could be argued that both Voina and Women on Waves both make actions already conceived and composed for their later media distribution. Lambert-Beatty theorizes that Women on Waves' mobile clinic is actually a kind of red herring, or type of disinformation, that distracts from their real goal - that of 'media politics' (LambertBeatty 2008: 320). While the act of actually performing abortions is crucial (and saving lives from botched illegal abortions is laudable) the symbolic potential on the imagination should not be overlooked and could potentially have a greater effect in the long-term - despite the current negligible effect on abortion law. As Lambert-Beatty points out, the inclusion of $A-P o r t a b l e$ in the $49^{\text {th }}$ Venice Biennale was not accessible to the general public; its exhibition only represented the real version, which was in Ireland (2008: 321). However, this symbolic version started rumours that the clinic could be visited, but only by women seeking gynaecological care. This helps to give the artwork mythical status. Similarly, Oliver Johnson has argued that the Voina group actions are 'open-ended provocations that rely on the response of the authorities, the media and the mass audience' to complete the work (2013: 599). Voina actions are composed and documented aesthetically to become future internet icons. Seen in this way, both Voina and Women on Waves are media artists. Voina détourne their arrests and international arrest warrants to foster a mythical outlaw status.

Both these groups construct stories that ignite the imagination - what if we stood up to the authoritarian state in the face of human rights abuses? What if all women had access to free and safe birth control? Their actions demonstrate such possibilities (in short-term tactical interventions) and their media representations create slowburning ideas. It is not that people in Ireland, Poland and other countries where 
abortion is illegal were unaware of this possibility. Nor is it the case that Russians are unaware of more liberal forms of democracy. However, sometimes it takes a symbolic gesture to remind people that these alternatives are real and achievable - if they want them.

\section{INSERT FIGURE 2 HERE.}

Symbolic gestures, however, can easily become banal and toothless. Take, for example, One Two Three, Swing! (2017) by the Danish art collective Superflex (founded 1993). Superflex intended to combat apathy by getting visitors to participate in their artwork. Swings with seats designed for three people were installed in Tate Modern's Turbine Hall. Supposedly swinging together focusses on collective action and therefore combats individualism and selfishness. The swings (which were later installed on the lawn outside Tate Modern) only formed one third of the installation. A pendulum suspended from the ceiling above a floor carpeted with a special design derived from the colour scheme of British bank notes comprises the first third, which supposedly represents apathy. In the second third, a factory installed in the gallery demonstrating how the swing seats are manufactured represents production. The swings represent movement.

One Two Three, Swing! has been much maligned. A review in Art in America felt that British reserved personalities meant that in reality people were reticent to approach strangers to form new groups of three. The critic also noticed that children scrambling to get involved suggested that 'the playground format actively encourages competition and selfishness' (Coxhead 2018: 37). For these reasons, and because of Superflex's assumptions about apathy holding back social change, he deemed the installation 'unbearably naive' (Coxhead 2018: 37). The Daily Telegraph declared that it was a 'whimsical exercise of shallow metaphor' and 'possibly the worst Turbine Hall commission yet' (Hudson 2017), while The Observer described it as 'by far the worst Turbine Hall commission in the history of Tate Modern' and 'astonishing in its banality' (Cumming 2017). 
It is true that, having had a go on the swings, the general public is unlikely to be transformed into revolutionary subjects, however there is potential for critical reflection in this artwork. Participants might draw parallels between the building, a former power station, and the generation of energy when working together. They might also ponder the connections between currency, production and motion. They might ask what connections there are between the swinging pendulum (which they apparently have no control over) and the playground style swings (which only move if the public activates them). The exhibition wall text explained that the collective power of swinging might change the trajectory of the planet: presumably this would be detectable in the Foucault Pendulum, which could be understood to represent global capitalism.

Voina's actions or Women on Waves' abortion ship - whether experienced directly or through the rumours and myths that they generate - are both much more likely to encourage people to organize and enact social change than Superflex's One Two Three Swing! Inviting people to play on swings, like kids, hardly ensures serious reflection. The problem, one might argue, is that people already know the deficiencies of our political system, but they suffer from 'oh-dearism'. What they need to see are creditable alternatives: to see how change can really happen to break their apathy. Superflex's call for an end to apathy and for a return to collective action fails to address the quality of social action: presumably they would not applaud the recent rise of populism, for example. Changing the earth's trajectory using playground equipment seems so far-fetched that they might just as well end up playing - what more apathetic response is there?

\section{Conclusions}

Political and social change can happen when you least expect it (recall the example of the last days of the Soviet Union, for example). Artists are not responsible for planning, envisaging and implementing new political systems. However, they can play a key role. All that is required of artists is to ignite public imagination. This alone may prove to be the catalyst that puts a chink in the veil of the spectacular malaise. Fisher believed that 
'the tiniest event can tear a hole' in the spectacle (2009: 81). Following this logic, microincursions are all that is needed is to take us from a situation where 'there is no alternative' to one where anything is possible. Actions such as those by Women on Waves or Voina are more effective in this regard than the example by Superflex, because their actions address concrete issues and demonstrate alternatives. Voina and Women on Waves take real risks and deal with controversial issues, generating media coverage and what Suzanne Lacy calls an 'audience of myth and memory' (Lacy 2010: 178).

Critics might argue that the dystopian, pervasive power of capitalism that Debord warned against has arrived: that his book served more as an instruction manual for neo-liberals. On the other hand, the text also might also serve as a handbook for resistance, or a call to arms. Art activists can play a key role in countering and revealing concepts such as spectacle and disinformation where they arise by applying Fisher's call to demonstrate alternative possibilities and reveal contingency in apparently natural orders. Revealing and demonstrating can quickly lead to undermining and, while it might not make immediate social or political change, this symbolic gesture strikes directly at the spectacular malaise. Where Surkov uses disinformation 'not to win the war, but to use the conflict to create a constant state of destabilized perception' (Curtis 2016), artists can reveal disinformation to create a state of clarity.

\section{References}

Amnesty International (2019), '10 things you need to know about abortion laws in the US', June 11, https://www.amnesty.org/en/latest/news/2019/06/abortion-lawsin-the-us-10-things-you-need-to-knowl. Accessed 9 August 2019.

Anon (2011), 'Bank reforms: how much did we bail them out and how much do they still owe?', The Guardian 12 November, https://www.theguardian.com/news/datablog/2011/nov/12/bank-bailouts-uk-creditcrunch. Accessed 19 February 2017. 
Associated Press (2019), 'Trump administration to ban abortion referrals at taxpayerfunded clinics', The Guardian, July 16, https://www.theguardian.com/world/2019/jul/16/trump-administration-to-beginenforcing-abortion-restrictions. Accessed 9 August 2019.

Badiou, Alain (2012), The Rebirth of History: Times of Riots and Uprisings (Trans. G. Elliott), London; New York: Verso.

BBC (2017), 'Trump reverses foreign abortion policy', BBC News, January 23, https://www.bbc.com/news/world-us-canada-38724063. Accessed 9 August 2019.

BBC (2018), 'Anger in Poland over abortion limits bill', BBC News, March 26, https://www.bbc.com/news/world-europe-43514965. Accessed 9 August 2019.

Boffey, Daniel (2015), 'Return of Rebekah Brooks is "two fingers up to British public" - shadow minister', The Guardian, 29 August, http://www.theguardian.com/media/2015/aug/29/rebekah-brooks-return-newsuk-chief-campaigners-attack-report-rupert-murdoch. Accessed 4 July 2018. Bulman, May (2018), 'Thousands take to Poland's streets to oppose tightening of abortion law', The Independent, March 24, https://www.independent.co.uk/news/world/europe/poland-abortion-protestmarch-black-friday-streets-womens-rights-a8271866.html. Accessed 10 August 2019.

Bush, George H.W. (n.d.), 'President George Bush speech announcing war against Iraq', The History Place: Great Speeches Collection, http://www.historyplace.com/speeches/bush-war.htm. Accessed 14 August 2019.

Considine, Liam (2015), 'Screen politics: Pop Art and the Atelier Populaire', Tate Papers, 24, https://www.tate.org.uk/research/publications/tate- 
papers/24/screen-politics-pop-art-and-the-atelier-populaire. Accessed 27

October 2018.

Coxhead, Gabriel (2018), 'Socially awkward', Art in America, January, 106:1, pp. 3538.

Cumming, Laura (2017), 'Superflex: One Two Three Swing!; Martin Puryear review lows and highs', The Observer, 8 October, https://www.theguardian.com/artanddesign/2017/oct/08/one-two-three-swingsuperflex-review-tate-modern-turbine-hall-martin-puryear-parasol-unit. Accessed 13 August 2019.

Curtis, Adam (2011), interviewed by Budzinski, Nathan, 'An interview with Adam Curtis', The Wire, July, https://www.thewire.co.uk/in-writing/interviews/aninterview-with-adam-curtis Accessed 1 November 2017. (2016), Hypernormalisation, UK: BBC

http://www.bbc.co.uk/iplayer/episode/p04b183c/adam-curtis-hypernormalisation. Accessed 2 February 2017.

Dark Star (ed) (2001) Beneath the Paving Stones: Situationists and the Beach, May 1968. Edinburgh: AK Press/Dark Star.

Dean, Jodi (2009), Democracy and Other Neoliberal Fantasies: Communicative Capitalism and Left Politics. Durham NC: Duke University Press.

Debord, Guy (1973), La Société du Spectacle (The society of the Spectacle). France: Simar Films. (1998), Comments on The Society of the Spectacle. (Trans. M. Imrie), London: Verso. (2004), The Society of the Spectacle, (Trans. K. Knabb), London: Rebel Press.

Fišera, V.C. (1978), Writing on the Wall, May 1968: A Documentary Anthology, London: Allison \& Busby. 
Fisher, Mark (2009), Capitalist Realism: Is There No Alternative? Winchester: 0 Books.

Fukuyama, Francis (1992), The End of History and the Last Man, London: Hamilton.

Gallix, Andrew (2009), 'The resurrection of Guy Debord', The Guardian, 18 March, https://www.theguardian.com/books/booksblog/2009/mar/18/guy-debordsituationist-international. Accessed 27 October 2018.

Graeber, David (2009), Direct Action: An Ethnography, Edinburgh: AK Press.

Grindon, Gavin (2008), 'Introduction', in G. Grindon (ed.), Aesthetics and Radical Politics, Newcastle upon Tyne: Cambridge Scholars, pp.vii-xvii. (2009), 'Second-wave Situationism?', Fifth Estate, Summer, pp.11, 5051.

Hacked Off (2015), 'Hacked Off respond to news of Rebekah Brooks News UK return'. Hacked Off: Campaign for a Free and Accountable Press, 31 August, https://hackinginquiry.org/hacked-off-respond-to-reports-of-rebekah-brooks-newsuk-return/. Accessed 4 July 2018.

Harvey, David (2012), Rebel Cities: From the Right to the City to the Urban Revolution, London: Verso.

Holloway, John (2012), 'Afterword: rage against the rule of money', in F. Campagna and E. Campiglio (eds), What We Are Fighting For, London: Pluto Press, pp.199205.

Hudson, Mark (2017), 'A whimsical exercise of shallow metaphor: Superflex, Tate Modern', The Daily Telegraph, 2 October 2017, https://www.telegraph.co.uk/art/what-to-see/whimsical-exercise-shallowmetaphor-superflex-tate-modern/. Accessed 13 August 2019.

Johnson, Oliver (2013), 'War on the Ru-net: Voina's Dick Captured by the FSB as a networked performance', Third Text 27:5, pp.591-606.

Knabb, Ken (ed.) (2006), Situationist International Anthology, rev. ed., (Trans. K. Knabb), Berkeley, CA: Bureau of Public Secrets. 
(2011), 'The Situationists and the occupation movements: 1968/2011',

Bureau of Public Secrets, http://www.bopsecrets.org/recent/situationists-

occupations.htm. Accessed 2 February 2017.

Kurczynski, Karen (2010), 'Situationism', Oxford Art Online. Oxford: Oxford University Press, https://doi.org/10.1093/gao/9781884446054.article.T2086071. Accessed 14 September 2018.

Lacy, Suzanne. (2010), 'Debated territory: toward a critical language for public art', in S. Lacy (ed.), Leaving Art: Writings on Performance, Politics, and Publics 19742007, Durham NC; London: Duke University Press, pp.172-184.

Lambert-Beatty, Carrie (2008), 'Twelve miles: boundaries of the new art/activism', Signs: Journal of Women in Culture and Society, 33:2, pp.309-327.

Lasn, Kalle (2000), Culture Jam: How to Reverse America's Suicidal Consumer Binge and Why We Must, New York: Quill.

McKee, Yates (2016), 'Occupy and the end of socially engaged art' e-flux, 72, http://www.e-flux.com/journal/72/60504/occupy-and-the-end-of-socially-engagedart/. Accessed 26 January 2018.

Moore, Michael (2004), Fahrenheit 9/11, USA: Fellowship Adventure Group. Pomerantsev, Peter (2014a), 'Non-linear war', London Review of Books, 28 March, https://blog.Irb.co.uk/blog/2014/march/non-linear-war. Accessed 5 August 2019.

Pomerantsev, Peter (2014b), 'The hidden author of Putinism', The Atlantic, 7 November, https://www.theatlantic.com/international/archive/2014/11/hiddenauthor-putinism-russia-vladislav-surkov/382489/. Accessed 7 August 2019.

Precarious Workers Brigade (n.d.) 'About', Precarious Workers Brigade, https://precariousworkersbrigade.tumblr.com/about. Accessed 12 August 2019.

Quaintance, Morgan (2016), 'Rules of engagement' Art Monthly, October, 400, pp. 710. 
RETORT (2004), 'Afflicted powers: the state, the spectacle and September 11', New Left Review, 2:27, pp.5-21.

(2006), 'An exchange on Afflicted Powers: capital and spectacle in a new age of war', October, 115, pp.3-12.

Sanger-Katz, Margot (2018), 'Is terrorism getting worse? In the West, yes. In the world, no', The New York Times, 20 January, https://www.nytimes.com/2016/08/16/upshot/is-terrorism-getting-worse-in-thewest-yes-in-the-world-no.html. Accessed 6 July 2018.

Seidman, Michael (2004), The Imaginary Revolution: Parisian Students and Workers in 1968, International Studies in Social History, New York: Berghahn Books.

Sloterdijk, Peter (2010), Rage and Time: A Psychopolitical Investigation (Trans. M. Wenning), New York; Chichester: Columbia University Press.

Smith, Meagan and Zeigler, Sean (2017), 'Terrorism before and after 9/11 - a more dangerous world?', Research \& Politics, 4:4, pp.1-8.

Standing, Guy (2016), The Precariat: The New Dangerous Class, Bloomsbury Revelations, London: Bloomsbury Academic.

Stowell, Joshua (2018), 'What is hybrid warfare? Non-linear combat in the 21st Century', Global Security Review, https://globalsecurityreview.com/hybrid-andnon-linear-warfare-systematically-erases-the-divide-between-war-peace/. Accessed 7 August 2019.

Thompson, Nato (2012), 'Living as form', in N. Thompson (ed.) Living as Form: Socially Engaged Art From 1991-2011, New York; Cambridge MA: Creative Time Books; MIT Press, pp.16-33.

Viénet, René (2014), Enragés and Situationists in the Occupation Movement, (Trans. L. Goldner and P. Sieveking), New York; London: Autonomedia; Rebel Press, http://www.cddc.vt.edu/sionline/si/enrages.html. Accessed 4 June 2018. 
Walgrave, Steffan and Rucht, Dieter (2010), The World Says No to War:

Demonstrations Against the War on Iraq, Minneapolis: University of Minnesota Press.

Walker, Shaun (2016), 'Kremlin puppet master's leaked emails are price of return to political frontline', The Guardian, 26 October

https://www.theguardian.com/world/2016/oct/26/kremlin-puppet-masters-leakedemails-vladislav-surkov-east-ukraine. Accessed 7 August 2019.

Wollen, Peter (1989), 'The Situationist International' New Left Review I: 174, pp.6795.

Žižek, Slavoj (2012), The Year of Dreaming Dangerously, London: Verso. 


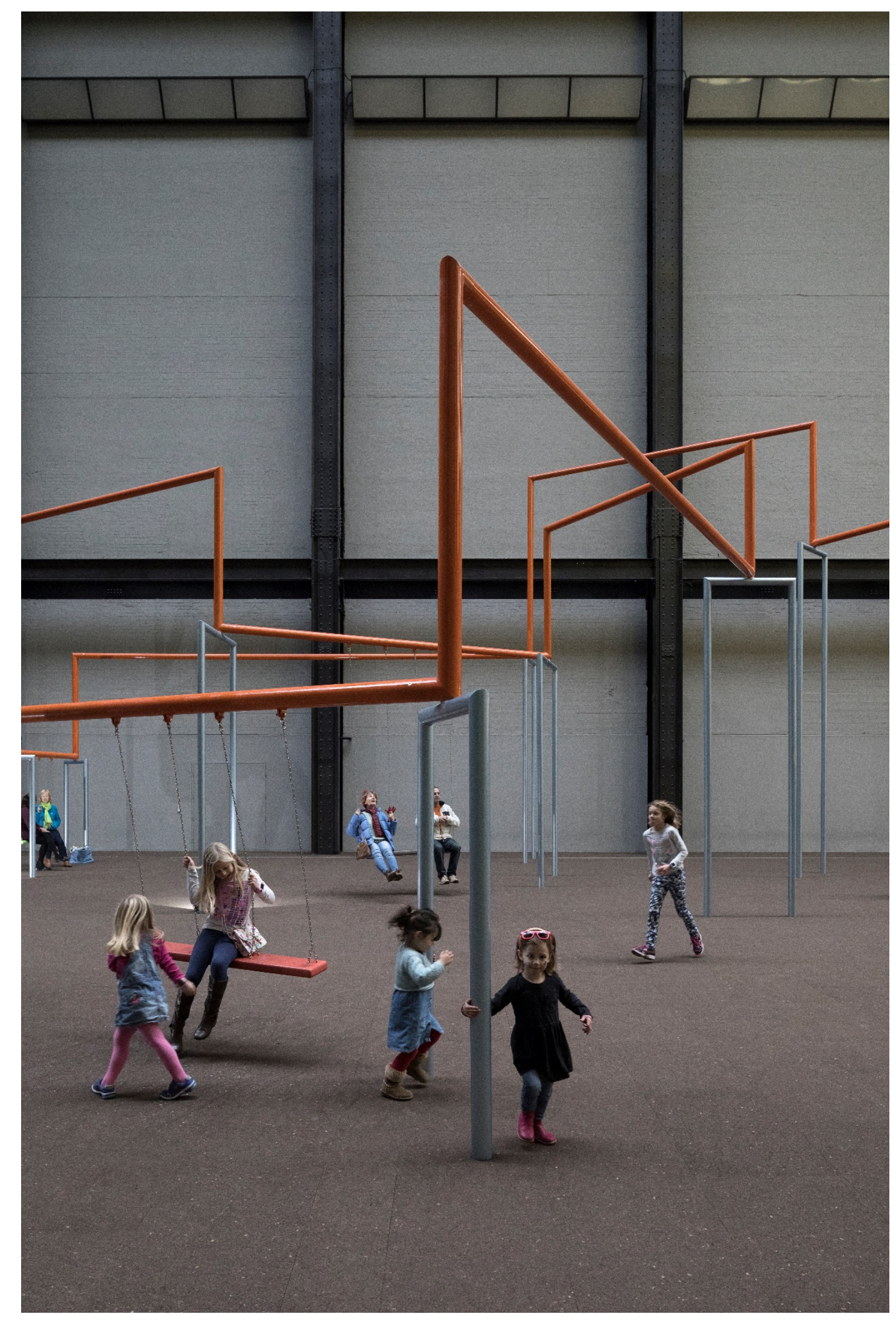

Figure 2: SUPERFLEX, One Two Three Swing!, 2017 (Tate Modern). Photo: Torben Eskerod 


\section{Notes}

1 Jodi Dean provides a clear summary of 'post-politics' presenting two positions: 'postpolitics as an ideal of consensus, inclusion, and administration that must be rejected' (a view held by Chantal Mouffe and Jacques Rancière) and 'post-politics as a description of the contemporary exclusion or foreclosure of the political' (a view held by Slavoj Žižek and Wendy Brown) (Dean 2009: 13). Alain Badiou is another key theorist associated with a discourse claiming the nomenclature of post-politics. These theorists all work within a Marxist, or postMarxist tradition.

${ }^{2}$ As alleged by several commentators, including Michael Moore in his feature documentary Fahrenheit 9/11 (2004).

${ }^{3}$ Conscription for warfare (as opposed to military service during peace-time) ended before 1991 in North American and most European countries. In the United Kingdom conscription ended in 1963. In the United States conscription was controversial during the 1960s. Nixon stood for the presidency in 1968 on a promise to end conscription. In fact, he extended it until 1973 (the last men were drafted in 1972) when conscription in the United States effectively ended. At the start of the first Gulf War, President Bush felt the need to reassure Americans that would not 'be another Vietnam' (Bush, 1991). Conscription after 1991 seemed unthinkable in the West. However, today, all male US citizens and immigrant non-citizens are required to register for the Selective Service system - within thirty days of their $18^{\text {th }}$ birthday (or point of entry).

${ }_{4}$ Since 9/11, Islamist terrorist attacks on western soil have included: Atocha railway station (Madrid, 2004) and on the London tube and bus networks (2005) the beheading of fusilier Lee Rigby (London, 2013), the Charlie Hebdo Shooting and the Bataclan Theatre attack (both Paris, 2015), the Bastille day attack where a 19-tonne truck was deliberately driven into tourists on the Promenade des Anglais (Nice, 2016), the Westminster and London Bridge attacks (London, 2017) and the Manchester Arena bombing (2017). This list is not exhaustive.

5 Such an argument has been made by Morgan Quaintance (2016). Such artists, he observes, often make video, installation and socially engaged artworks that involve discourse. Their aim is to not be prescriptive, or to allow the artworld to project notions of social engagement onto their work, but for their work to embody such notions, without the need for a critic to reveal or draw them out. 